\title{
The Application of Flipped Classroom in the Teaching of Translation for College English Majors
}

\author{
Tian Ling \\ School of Foreign Languages \\ Yan'an University \\ Yan'an China \\ lingtian77@126.com
}

\begin{abstract}
Flipped classroom is a new teaching model, which inverts the process of knowledge transfer and knowledge absorption and changes the students' and the teacher's role. The author has applied flipped classroom in translation teaching for college English majors for some time. In order to show the concrete application method and evaluate the teaching effect, the paper introduces a model class of the teaching of the translation technique amplification, and uses such research instruments as a questionnaire, an interview and the comparison of the students' translation works. The result of the evaluation shows that flipped classroom model can be well applied in translation teaching, but some factors need to be considered as well. The paper is different from previous studies in that the author applies flipped classroom in the teaching of translation for college English majors and the teaching effect is also evaluated by various research instruments.
\end{abstract}

Keywords-flipped classroom; the teaching of translation; English Majors; translation technique

\section{THE INTRODUCTION TO FLIPPED ClASSROOM}

Flipped classroom, as the product of technology development, is a new teaching model. It can be dated back to the year 2004. In that year, Salman Khan made some teaching materials into videos and uploaded them onto the You Tube Website. Then attention was quickly aroused among the people. Soon he founded the Khan Research Institute. In 2007, two chemistry teachers Jonathan Bergmannn and Aaron Sams from US Woodland Park High School made their teaching PowerPoint and the lecture into videos, so that the truants can watch them afterwards. But their videos drew more attention than they expected. Not only the truants but also other students began to watch them at home. Thus flipped classroom model was gradually formed. According to it, students watch the teaching videos and read other teaching materials before class, and the teacher answers the students' questions and organizes different kinds of activities in class in order to arouse the students' interests and test whether the students have grasped the teaching contents. It inverts the traditional teaching model in that the transfer of knowledge is done before class, while the absorption of knowledge in class. That is completely different from the traditional teaching model.

The essence of flipped classroom is the prolonged time for preview since the students have a lot of things to do before class, such as watching the teaching videos, reading relevant materials and doing the exercises. Hence the advantage of this new model is obvious: students can better display their subjective initiative. In traditional class, students just sit in the classroom and listen to the lecture passively, without much subjective initiative. But now things are quite different. Students can watch the videos before class and they can decide how many times they watch them according to their own needs And during the watching, they can write down their difficulties, and then in class they may ask the teacher questions with a clear aim. Thus in class the teacher has more time to answer the students' questions and students have more chances to have a discussion with their partners and show their own achievements. The time in class can be used more effectively. Under the guidance of this model, the teacher's role is changed from a knowledge imparter into an organizer, while the students change their role from passive acceptors into active learners. The students can learn knowledge more actively and purposefully. Thus Aaron Sams says, flipped classroom makes the teacher shoulder more responsibilities by changing the students' and the teacher's role. This model requires professional educators with the sense of responsibility, love and the ability of design. [1]

\section{The Design of Translation TEACHING With the Help OF FLIPPED CLASSROOM}

According to National Program for Medium to Long-Term Educational Revolution and Development, we should learn from international advanced educational theories and experience to push forward the development of our educational revolution and promote China's educational status, influence power and competitive strength in the world. [2] Thus it is suitable to apply flipped classroom in our teaching, especially for the courses that require much students' participation in class.

In college education, translation ability is a very important skill for English majors. Translation course calls for more students' participation since it involves not only theories but also a lot of practice. So the students' subjective initiative plays a very important role in the study of translation. But traditional teaching model is not satisfying in that the teacher dominates the class. Students' participation mainly lies in doing some exercises and they can't show much subjective initiative. The limited participation of the students leads to the fact that students lose interests in translation study and their translation

Sponsor: Shaanxi Educational Science Research Program. 
abilities can't be improved a lot. Therefore, theoretically speaking, flipped classroom, which gives many chances for students to participate in kinds of teaching activities and makes full use of students' subjective initiative, can be applied in the teaching of translation. What's more, college students have the self-taught ability, and computers are available for them either in the dormitory or in the library. It's convenient for them to watch the teaching videos and they can control their own behaviors. And most teachers have grasped modern educational technology. The combination of flipped classroom with the teaching of translation gives full time for students to preview and meets different demands. Therefore, in both aspects it's suitable to apply flipped classroom in the teaching of translation for college English majors.

In view of that, the author has carried out the plan for a time and achieved a certain effect. Here one model class will be given to show the concrete application method. That is about the teaching of a technique Amplification in EnglishChinese (E-C) translation.

\section{A. Activities before Class}

Before class, the teacher gives a short paragraph of about 200 words for the students to translate, which needs to use the technique of amplification. During the translation process, they may refer to a dictionary or other reference books. And then they should take down their problems and hand in their assignments on line after 1 hour. The teacher reads their translation and records their marks. And then the students may watch the teaching video, which includes the definition of amplification, the principles of amplification, the words usually amplified as well as some examples. The video lasts for 10 minutes, with the teacher's teaching PPT and lecture involved. When they watch it, they may take notes and write down their puzzles, so that they may consult the teacher in class and take part in group discussions. If the students can't understand the teaching content, they may watch the video again and again until they have grasped it. In addition, students are required to read relevant materials in their textbooks and some hand-out of more examples.

\section{B. Activities in Class}

According to Constructivism, the acquisition of knowledge is a process of students constructing meaning by interpersonal cooperation under a certain circumstance. [3] Therefore, in applying flipped classroom the teacher should ask the students to cooperate with each other. To be specific, students may solve their translation problems by team work. In class the students are divided into several groups, each group having 4 members. In the group, they can discuss the problems they meet in watching the video and doing their translation exercises with their partners. They may exchange their translation gains and loss and then analyze each student's translation and get a better one for their own group. Next the representative of each group reports the result of their discussion, which includes their gains and puzzles, and shows the achievements of their team translation in class. The teacher gives some comments and helps to solve the problems. Then each group makes a second discussion and improves their translations according to the teacher's comments. Next some time is left for the students to ask questions. At last the teacher gives students another paragraph of about 200 words for the students to translate, which has the same difficulty value as the previous one and also calls for the use of the translation technique amplification.

\section{Activities after Class}

After class, the students are given another 1 hour to translate that paragraph and are required to hand in the assignment on line. The mark will also be recorded. The teacher gives the feedback after the reading of the translation. The students may ask the teacher questions about the teaching content and talk about the difficulties they meet in their translation. And then the students are required to write a journal about the whole lesson, which may include their gains, puzzles, the way to solve problems and the things they need to notice in their future study. Surely, the form of the journal depends on the students, which may be formal or casual, or even include something they want to tell to the teacher. All these interactive activities are done on line. The teacher also needs to compare the two translation assignments to see whether students can do a better job in the second time. This comparison not only involves the marks, but also the specific kinds of mistakes the students make.

\section{The Evaluation OF THE TEACHING EFFECT}

The author has applied flipped classroom model for two months in translation teaching. It seems students actively participate in all kinds of activities and show a lot of interests in the new model. But in order to evaluate the teaching effect more scientifically, the author uses such research instruments as a questionnaire, an interview and the comparison of the students' translation works. First, a questionnaire is handed out for a class of 20 students. It is composed of 12 questions with the aim of finding out the students' attitudes towards flipped classroom. Questions 1-4 are designed to know whether the students are interested in it.

TABLE I. STATISTICS OF THE ANSWERS TO QUESTIONS 1-4

\begin{tabular}{|c|l|l|l|l|}
\hline 1 & $\begin{array}{l}\text { I like flipped classroom teaching } \\
\text { model. }\end{array}$ & $\begin{array}{l}\text { agree } \\
91.5 \%\end{array}$ & $\begin{array}{l}\text { disagree } \\
3.5 \%\end{array}$ & $\begin{array}{l}\text { no idea } \\
5 \%\end{array}$ \\
\hline 2 & $\begin{array}{l}\text { Flipped classroom can arouse my } \\
\text { interest in translation study. }\end{array}$ & $\begin{array}{l}\text { agree } \\
90 \%\end{array}$ & $\begin{array}{l}\text { disagree } \\
4 \%\end{array}$ & $\begin{array}{l}\text { no idea } \\
6 \%\end{array}$ \\
\hline 3 & $\begin{array}{l}\text { I think flipped classroom model is } \\
\text { better than the traditional one. }\end{array}$ & $\begin{array}{l}\text { agree } \\
90.3 \%\end{array}$ & $\begin{array}{l}\text { disagree } \\
5.1 \%\end{array}$ & $\begin{array}{l}\text { no idea } \\
4.6 \%\end{array}$ \\
\hline 4 & $\begin{array}{l}\text { I hope the teacher will continue } \\
\text { using flipped classroom in } \\
\text { translation teaching. }\end{array}$ & $\begin{array}{l}\text { agree } \\
90.8 \%\end{array}$ & $\begin{array}{l}\text { disagree } \\
4.7 \%\end{array}$ & $\begin{array}{l}\text { no idea } \\
4.5 \%\end{array}$ \\
\hline
\end{tabular}

Questions 5-8 are designed to see how the students think about the effect of flipped classroom in translation teaching. 
TABLE II.

STATISTICS OF THE ANSWERS TO QUESTIONS 5-8

\begin{tabular}{|c|c|c|c|c|}
\hline 5 & $\begin{array}{c}\text { Flipped classroom model can help } \\
\text { me improve my translation ability. }\end{array}$ & $\begin{array}{c}\text { agree } \\
89.8 \%\end{array}$ & $\begin{array}{c}\text { disagree } \\
5.7 \%\end{array}$ & $\begin{array}{c}\text { no idea } \\
4.5 \%\end{array}$ \\
\hline 6 & $\begin{array}{c}\text { Flipped classroom model can help } \\
\text { me improve my linguistic ability. }\end{array}$ & $\begin{array}{c}\text { agree } \\
87.5 \%\end{array}$ & $\begin{array}{c}\text { disagree } \\
7 \%\end{array}$ & $\begin{array}{c}\text { no idea } \\
5.5 \%\end{array}$ \\
\hline 7 & $\begin{array}{c}\text { Flipped classroom model can help } \\
\text { me improve my ability of self- } \\
\text { control. }\end{array}$ & $\begin{array}{c}\text { agree } \\
93.1 \%\end{array}$ & $\begin{array}{c}\text { disagree } \\
2.7 \%\end{array}$ & $\begin{array}{c}\text { no idea } \\
4.2 \%\end{array}$ \\
\hline 8 & $\begin{array}{c}\text { Flipped classroom model can help } \\
\text { me improve my communicative } \\
\text { competence. }\end{array}$ & $\begin{array}{c}\text { agree } \\
96 \%\end{array}$ & $2 \%$ & $\begin{array}{c}\text { disagree } \\
\text { no idea }\end{array}$ \\
& \begin{tabular}{c}
$2 \%$ \\
\hline
\end{tabular} & & & \\
\hline
\end{tabular}

Questions 9-12 are designed to see in which aspects flipped classroom model should be improved.

TABLE III. STATISTICS OF THE ANSWERS TO QUESTIONS 9-12

\begin{tabular}{|c|c|c|c|c|}
\hline 9 & $\begin{array}{l}\text { I think the teaching videos are very } \\
\text { instructive and useful. }\end{array}$ & $\begin{array}{l}\text { agree } \\
92.2 \%\end{array}$ & $\begin{array}{c}\text { disagree } \\
6.3 \%\end{array}$ & $\begin{array}{c}\text { no idea } \\
1.5 \%\end{array}$ \\
\hline 10 & $\begin{array}{l}\text { I think the assignments are suitable } \\
\text { for me. }\end{array}$ & $\begin{array}{l}\text { agree } \\
97 \%\end{array}$ & $\begin{array}{c}\text { disagree } \\
1 \%\end{array}$ & $\begin{array}{c}\text { no idea } \\
2 \%\end{array}$ \\
\hline 11 & $\begin{array}{l}\text { I think the activities in class are } \\
\text { useful and interesting. }\end{array}$ & $\begin{array}{l}\text { agree } \\
95.4 \%\end{array}$ & $\begin{array}{c}\text { disagree } \\
3.1 \%\end{array}$ & $\begin{array}{c}\text { no idea } \\
1.5 \%\end{array}$ \\
\hline 12 & $\begin{array}{l}\text { I think the interactive activities } \\
\text { with the teacher are effective. }\end{array}$ & $\begin{array}{l}\text { agree } \\
91.8 \%\end{array}$ & $\begin{array}{c}\text { disagree } \\
4.4 \%\end{array}$ & $\begin{array}{c}\text { no idea } \\
3.8 \%\end{array}$ \\
\hline
\end{tabular}

From the statistics of the questionnaire, it can be seen that most of the students like flipped classroom model; they are interested in it and hope the teacher will use the model in the future. What's more, students hold that flipped classroom model can improve their diverse aspects of ability, such as translation ability, linguistic ability, communicative competence, and so on. At last, most students think the present teaching model is suitable and effective for them. They are generally satisfied with it.

In addition, with an eye to know more about the students' attitudes and further improve flipped classroom model, the author also makes an interview among three students. One is good in translation; one is medium-leveled, while another is poor-leveled. The questions are as follows: 1 . What benefit you most in flipped classroom model? 2. What advice do you have for the future use of flipped classroom model in translation teaching?

As for question 1, the students' answers mainly focus on the improvement of their self-taught ability and communicative competence. And in the long run, their translation ability gets improved as well. As for question 2, some students advise to choose more interesting examples so that the teaching videos may be more attractive; some think the interactive activities with the teacher can be increased in frequency; some others hold that the activities in class can also imitate real translation projects so that the students can be qualified for a translator in the future. That is similar to what a scholar once says, in the present application of flipped classroom, a popular model among the educators is the study based on projects. By proposing a problem or a project, the teacher actually makes the students finish knowledge construction by their own exploration. [4]

In order to have a more objective evaluation to the effect of flipped classroom model in translation teaching, the author also makes a comparison between the marks of the two assignments (the one before class and the one after class). With the same difficulty value and evaluation standard, the author finds the average mark has improved by 5 points. And in the second assignment the students get to know how to use the translation technique in proper occasions. What's more, due to the use of the technique, the students' translations become more faithful and expressive.

\section{CONCLUSION}

According to the theoretical demonstration and practical examination, flipped classroom model can be well applied in the teaching of translation for college English majors. The combination of the two can arouse students' interests and further promote the students' translation abilities. But something needs to be noticed. On one hand, flipped classroom model can not be used in all the teaching contents. In applying flipped classroom, we can not follow suit just because it is a new teaching model. [5] The author thinks that it is well used in the teaching of translation techniques since with the help of a lot of examples they are comparatively easy to understand. For those abstract theories, it is better to use the traditional method. On the other hand, the teacher and the whole school should work out more effective measures to supervise the students. It should be guaranteed that the students really watch the teaching videos before hand and that they carefully finish the assignment within a given time. If we wish that flipped classroom model can achieve good effects, there are really a lot of things to do. It is hoped that flipped classroom model can be better applied in different kinds of subjects and for different levels of students. We are confident to see a bright future of flipped classroom in our education.

\section{REFERENCES}

[1] Aaron Sams. \& Brian Bennett. The Truth about Flipped Learning [EB/OL]. http://www.eschoolnews.com/2012/05/31/

[2] State Council. National Program for Medium to Long-Term Educational Revolution and Development(2010-2020) [Z](in Chinese)

[3] He Kekang. Constructivism --- Theoretical Foundation of Innovating Traditional Teaching [J]. E-Research Education. 1997(3)(in Chinese)

[4] Zhang Jinlei. The Key Elements of Flipped Classroom Teaching Model [J]. Distance Education in China. 2013(10)(in Chinese)

[5] Wang Hong. The Design of Flipped Classroom Teaching Model [J]. Modern Educational Technology [J]. 2013(8)(in Chinese) 